\title{
ANALYSIS OF BONE IMPLANT TO CONTACT VALUE USING SCANNING ELECTRON MICROSCOPE IN POST IMMEDIATE IMPLANTS WITH ADDITION OF GEL-EXTRACTED ROSELLA FLOWER
}

\author{
MOHAMMAD DHARMAUTAMA*, BAHRUDDIN THALIB, YULI SUSANIAWATY, IRFAN DAMMAR, ANDI ADYTHA MIR \\ Department of Prosthodontic, Faculty of Dentistry, Hasanuddin University, Makassar, Indonesia. Email: mohdharmautama@gmail.com
}

Received: 20 September 2018, Revised and Accepted:9 December 2018

ABSTRACT

Objective: The objective of the study was to analyze the difference of bone to implant contact (BIC) value post-immediate implants with or without injecting rosella flower extracts gel in mongrel.

Methods: A total of 18 implants were inserted in 9 mongrel's dog. The implant was divided into two groups. The first one (test implant) was implanted immediately after injection of gel-extracted rosella flower $10 \%$, while another group (control implant) was implanted immediately after the tooth extraction. The histomorphometry analysis was done after 14, 28, and 56 days to find out the BIC value.

Result: The mean value of BIC rosella group was $63.44 \%$ and the mean value of the control group was $52.11 \%$, with p=0.041.

Conclusion: Rosella flower extract is able to shorten the inflammatory phase after implantation, accelerate and expand bone growth by spurring collagen deposition as well as inhibiting osteoclast activity.

Keywords: Implant, Rosella, Bone to implant contact.

(C) 2019 The Authors. Published by Innovare Academic Sciences Pvt Ltd. This is an open access article under the CC BY license (http://creativecommons. org/licenses/by/4. 0/) DOI: http://dx.doi.org/10.22159/ijap.2019.v11s1.19105

\section{INTRODUCTION}

A successful criterion for an implant is related to the maximum attachment of the bone which is in contact with the implant. The successful use of implant depends on osseointegration affected by several factors, such as biocompatibility of the implant, quality and quantity of the bone available, and the force that can cause mobility during bone healing time.

The properties of the implant surface determine the formation of new bone tissue and bone osseointegration. Requirements for implant materials include biocompatibility, bioactivity with surrounding tissue so that osseointegration can occur, provide mechanical properties that are compatible with the part replaced in the body, resistance to corrosion of fluid contained inside the body $[1,2]$.

The implant surface has been developed in the last decade concentrated in an attemptto provide a faster increase in the osseointegration process. Several modifications of the surface have been developed and currently used to improve the implant performance. The surface modification of titanium implants has been performed to be osteoinductive and osteoconductive so that osseointegration occurs, such as making the titanium surface bioactive by modifying the chemical composition and topography of the implant surface corresponding to bone cell retention on the surface of titanium implants [3].

Rosella flowers (biscus sabdariffa ) are beneficial for improving the health and stamina of the body because the rosella flowers contain Vitamin $\mathrm{C}$ and high essential minerals. Vitamin $\mathrm{C}$ of the rosella flowers is also believed to ward off cancer-causing free radicals. High calcium can prevent bone loss, while certain substances in the rosella can rejuvenate the body cells and protect the body from infection of bacteria and viruses (Budi Sutomo) [4].

According to the Indonesian Health Ministry, every $100 \mathrm{~g}$ of rosella contains 260-280 mg of Vitamin C, Vitamins D, B1, and B2. In addition, rosella contains high calcium (486 mg/100 g), magnesium, and omega 3.
The active ingredients of rosella petals are grossypeptin, anthocyanin, glucose hibiscin, niacin, riboflavin, beta-carotene, iron, polysaccharides, and flavonoids [5].

Numerous studies have also shown that rosella flower extract can help wound healing and as an anti-inflammatory. This study aims to see whether the roselle extract gel is able to accelerate the formation of new bone around the implant.

\section{METHODS}

This research is an experimental research with a post-test design with the control group. The research took place in Biofarmaka Laboratory, Hasanuddin University, Physics Laboratory, Universitas Negeri Makassar, from June to September 2017. The study was divided into three stages: Rosella gel preparation, implant installation, and evaluation using Scanning Electron Microscope (SEM).

a. Making rosella gel extract

The fresh rosella flower petals were washed and rinsed with clean running water to remove any sticky impurities and ants on it, then drained and aerated. Drying was done by heating in an oven with a temperature not $>50^{\circ} \mathrm{C}$. After drying, it is dried and pollinated with blender or pollinator until smooth. The dried rosella flowers were weighed as much as $100 \mathrm{~g}$, then took $\pm 500 \mathrm{ml}$ (1:5) of $96 \%$ ethanol solvent. Soak the dried simplicia powder of rosella flowers in ethanol for $24 \mathrm{~h}$ until the solvent was saturated. Furthermore, rosella extract was added by gel ingredients while homogenized to evenly in the gel base. $10 \%$ rosella flower gel extract was then put into a sterile disposable spoit container.

b. Preparation of experimental animals

Nine dogs were divided into three groups (days 14, 28, and 56). The mongrel dog was premedicated with atropine $0.2-2 \mathrm{mg} / \mathrm{kg}$ and xylazin 1-3 mg/kg intravenously. The dog underwent the extraction of the first left and right premolar teeth with forceps; then a sulcular incision was made along buccal and lingual side on the crystal wall. 
The distal socket was filled with hemospongostan. The tool depth gauge was used to measure the depth of the socket, the implant with the size of $1 \mathrm{~mm}$ longer than the size of depth gauge then be selected afterward. The drill was done in the apical socket using the final drill according to the diameter of the implant to be installed. An implant without rosella gel coated then be inserted to the mandibular first left premolar root as a control, then stitched. An implant with rosella gel coated was inserted into the mandibular first right premolar root as the study group, and then stitched. Infusion of $\mathrm{NaCl}$ or $\mathrm{RL}$ was installed intravenously for pre- and post-operation.

c. Observation using SEM

Specimens containing implants were cleaned from unnecessary waste. The implanted part was prepared for analysis using SEM. The implants were cleaned with $4 \%$ formalin solution for $10 \mathrm{~min}$, dehydrated with $70 \%$ ethanol, then dried/vacuum. The bone around implant was cut with micromotor carefully up to $2 \mathrm{~mm}$ of the implant border. Bone and surrounding tissue was prepared for subsequent cutting using microtomes at half the diameter of the implant so that it is divided into two parts. The adopted implant samples were observed using SEM with various magnifications.

d. Bone to implant contact (BIC)

BIC observe and calculate by percentage of the bone surface using formula

$$
\mathrm{BIC}=\frac{\begin{array}{l}
\text { Length of bonein contact } \\
\text { with implant thread }
\end{array}}{\text { Length of thread surface of implant }} \times 100 \%
$$

The procedure of this study was approved by ethics committee Faculty of Medicine, Hasanuddin University (Registration number UH17080559).

\section{RESULTS}

The increase of bone can be seen in Table 1.

The result showed that there was a difference in the increase of bone surface area attached to the control group and study group on each side assessed, while for the assessment of each group there was a different result. There is a significant changed for the bone area in left and right area for days 14,28 , and $56(\mathrm{p}=0.002$ and $\mathrm{p}=0.000$, left and right, respectively).

For the control group, a significant increase of bone surface area was observed on both observed sides of the screw. The size of the control group's surface area on day 14 was $67 \%$ and $71 \%$, day 28 was $77 \%$ and $80 \%$, and day 56 was $92 \%$ and $96 \%$.

In the study group, the increase of bone surface area was significant $(\mathrm{p} \leq 0.05)$ where the study group value on day 14 was $79 \%$ and $75 \%$, on day 28 was $84 \%$ and $85 \%$, and day 56 was $97 \%$ and $96 \%$.

Table 1 shows the difference between the control group and the significant study on day 14 in the right thread whereas days 28 and 56 there was no significant difference between the groups. The difference of bone surface between the control group and study group can be seen in Graphic 1.

\section{DISCUSSION}

Researches had shown that rosella gel is effective in increasing of bone surface area around the implant; it is because rosella has a high concentration of vitamins and minerals and also has the bioactive materials which function as anti-inflammatory. In this study, it was seen that more study groups formed the new bone than the control group on day 14, study group with rosella extract was seen the faster phase of inflammation so that the phase of proliferation more quickly occurred. There was also a significant difference in the formation of new bone an the day studied between groups, this is slightly different from the
Table 1: The difference in bone area values of both sides in the control and study groups based on the observed side

\begin{tabular}{llllll}
\hline Day & $\begin{array}{l}\text { Left } \\
\text { mean } \pm \text { SD }\end{array}$ & p value & Day & $\begin{array}{l}\text { Right } \\
\text { mean } \pm \text { SD }\end{array}$ & p value \\
\hline Day 14 & $73 \pm 0.05^{\mathrm{b}}$ & $0.002^{*}$ & Day 14 & $73 \pm 0.07^{\mathrm{a}}$ & $0.000^{*}$ \\
Day 28 & $83 \pm 0.04^{\mathrm{a}}$ & & Day 28 & $81 \pm 0.04^{\mathrm{a}}$ & \\
Day 56 & $92 \pm 0.04^{\mathrm{a}}$ & & Day 56 & $96 \pm 0.03^{\mathrm{a}}$ & \\
\hline
\end{tabular}

${ }^{a}$ Normality test: Shapiro-Wilk test, Sig $>0.05$; Data are normally distributed.

${ }^{b}$ Normality test: Shapiro-Wilk test, Sig $<0.05$; Data are not normally distributed. *Friedman Test, $\mathrm{p} \leq 0.05$; significant

Table 2: Bone area value of control group based on observation day

\begin{tabular}{llllll}
\hline $\begin{array}{l}\text { Control } \\
\text { group }\end{array}$ & $\begin{array}{l}\text { Left } \\
\text { mean } \pm \text { SD }\end{array}$ & p value & $\begin{array}{l}\text { Control } \\
\text { group }\end{array}$ & $\begin{array}{l}\text { Right } \\
\text { mean } \pm \text { SD }\end{array}$ & p value \\
\hline Day 14 & $67 \pm 0.02^{\text {a }}$ & $0.000^{*}$ & Day 14 & $71 \pm 0.06^{\mathrm{a}}$ & $0.002^{*}$ \\
Day 28 & $77 \pm 0.02^{\text {a }}$ & & Day 28 & $80 \pm 0.03^{\mathrm{a}}$ & \\
Day 56 & $95 \pm 0.04^{\mathrm{a}}$ & & Day 56 & $89 \pm 0.03^{\mathrm{a}}$ & \\
\hline
\end{tabular}

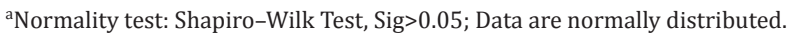

*Repeated ANOVA, pvalue $\leq 0.05$; Significant

Table 3: Bone area value of study group based on observation day

\begin{tabular}{llllll}
\hline $\begin{array}{l}\text { Study } \\
\text { group }\end{array}$ & $\begin{array}{l}\text { Left } \\
\text { mean } \pm \text { SD }\end{array}$ & p value & $\begin{array}{l}\text { Study } \\
\text { group }\end{array}$ & $\begin{array}{l}\text { Right } \\
\text { mean } \pm \text { SD }\end{array}$ & p value \\
\hline Day 14 & $79 \pm 0.02^{\text {a }}$ & $0.050^{*}$ & Day 14 & $75 \pm 0.01^{\text {b }}$ & $0.050^{*}$ \\
Day 28 & $84 \pm 0.02^{\text {b }}$ & & Day 28 & $85 \pm 0.02^{\text {a }}$ & \\
Day 56 & $97 \pm 0.02^{\text {b }}$ & & Day 56 & $96 \pm 0.01^{\text {a }}$ & \\
\hline
\end{tabular}

${ }^{a}$ Normality test: Shapiro-Wilk test, Sig $>0.05$; Data are normally distributed. *Repeated ANOVA, $\mathrm{p} \leq 0.05$; Significant

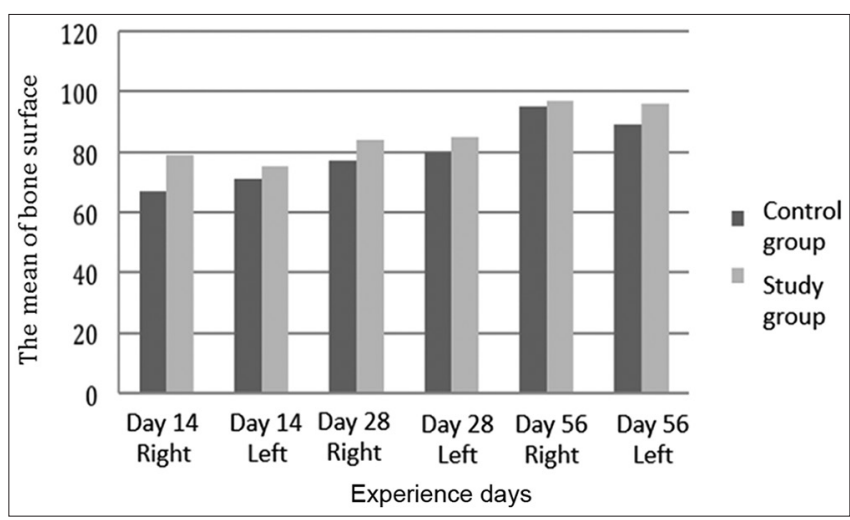

Graphic 1: The difference of bone surface value between groups on days 14,28 , and 56

study conducted by Gahlert et al. which states that there is a significant results on the bone surface area of day 28 and day 56 and after day 56 there is no significant difference in post-implantation bone growth between groups [6].

Several studies have shown that rosella flavonoids composed of flavanol compounds and anthocyanin pigments that act as antioxidants. In addition, rosella has also saponins as the active compounds. Flavonoids and saponins serve as an anti-inflammatory agent (Saptriani, 2012). Antioxidants in rosella have the inhibitory properties to cyclooxygenase enzyme activity in vitro.

The injury tissues due to tooth extraction procedure and implantation can lead to the mechanical and inflammatory process. The wound healing process will not occur if there is no inflammation and will be a source of pain. Wound healing begins with the formation of blood clots and subsequently followed by inflammatory phases on day 1-3, 


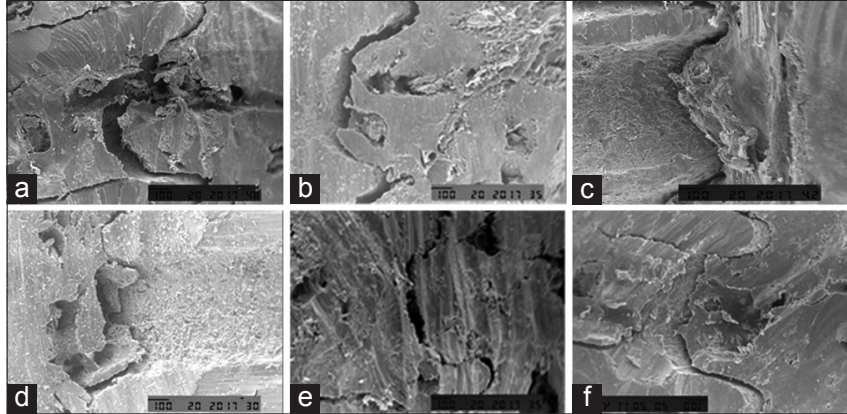

Fig. 1: Bone observation around the implant using scanning electron microscope (SEM) with $\times 200$ magnification. (a) SEM overview of control group on day 14, (b) SEM overview of control group on day 28, (c) SEM overview of control group on day 56 , (d) SEM overview of study group on day 14, (e) SEM overview of study group on day 28, (f) SEM overview of study group on day 56

proliferative phase on day 3-7, and remodeling on day 7-14 after injury. Inflammation responses must be controlled due to a long and persistent inflammatory response that will lead to more severe tissue damage, although an inflammatory response is a defense against an external lesion.

An in vitro study to assess the antioxidant and inhibitory potential of the rosella cyclooxygenase enzyme showed that the content of the rosella flower extract was able to inhibit the cyclooxygenase enzyme. Inhibition of the cyclooxygenase pathway is useful for reducing or eliminating inflammatory symptoms.

Numerous studies have also shown that rosella flower extract can help wound healing and act as an anti-inflammatory agent. A research conducted by Builders et al. (2013) found that the combination of gentamycin cream with rosella flower cream extract was able to provide a rapid wound healing effect. A research by Lenni stated that $10 \%$ rosella flower gel extract can be used as the anti-inflammatory agent in patients with gingivitis after acrylic crown cementation by decreasing the ratio of mRNA MMP-8/TIMP-1 [8].

Antioxidants in flavonoids can reduce or even eliminate inflammation with several mechanisms that bind free radicals directly, through inhibition of nitric oxide, inhibit the adhesion of leukocytes in blood vessel walls and interactions with other enzyme systems. Vitamin $C$ as a high antioxidant in rosella serves to improve bone formation which can help to absorb calcium by maintaining the calcium in the form of a solution, and assisting the growth of osteoblasts [9].

Another function of Vitamin C is to play the role in the various hydrolysis reactions required for the synthesis of collagen Keratinin and serotonin. Collagen is a protein compound that affects the integrity of cell structure in all connective tissues, such as in cartilage and bone matrix. Thus, Vitamin C can improve bone formation and play a role in the healing of fracture (Almatsier, 2002 and Wolf, 2005).

Calcium in rosella is high enough that is $486 \mathrm{mg} / 100 \mathrm{~g}$ and the phosphorus is $273.2 \mathrm{mg}$. The calcium can improve the bone density. The calcium in bone has two functions, as an integral part of the bone structure and as calcium reservoir. In the early growth of the fetus, calcium formed as the embryo of the growing bone. Then, the matrix is strengthened through the calcification process that is the formation of mineral crystals. Calcium and phosphorus are the main elements in the structure, so they should be just at the right amount of fluid that surrounds the bone structure [11].

In this study, both groups showed the increased bone growth on the day of this study because bone healing would be occurred either added by bioactive agent or nut, but on day 14 the study group was slightly higher with $79 \%$ of value compared to the control group that was only $67 \%$, this is due to the addition of rosella extract which has an anti-inflammation property, thus shortening the duration of the inflammatory process and the next phase was faster than the control group. The study did not show the quality of new bone formed so that requires further research.

\section{CONCLUSION}

The addition of bioactive rosella flower extract is able to shorten the inflammatory phase after implantation; it can also accelerate and expand bone growth by spurring collagen deposition and inhibiting osteoclast activity. The high enough calcium level can increase the volume of bone formed on the surface of the implant.

\section{CONFLICTS OF INTEREST}

There are no conflicts of interest to declare.

\section{REFERENCES}

1. Al-Sabbagh M. Implants in the esthetic zone. Dent Clin North Am 2006;50:391-407, vi.

2. Thevenot P, Hu W, Tang L. Surface chemistry influences implant biocompatibility. Curr Top Med Chem 2008;8:270-80

3. Richard T. Effect of addition of bioactive ingredients on dental implants based on histological examination. Makassar Dent J 2015;4:135-42.

4. Oktora L, Sari RK. Utilization of traditional medicines with benefits and safety considerations. Pharm Sci Mag 2006;3:1-7.

5. Mahadevan N. Hibiscus sabdariffa Linn an overview. Natl Prod Radian 2009;8:77-83

6. Han J. Osseointegration capacity of two types of zirconia implant. Int J Nanomedicin 2006;11:6507-16.

7. Sari LN. Effectiveness of Stardardized Ethanol Extract of Rosella Petals $7.5 \%$ and $15 \%$ Against Oral Mucous Ulcer Rats. Indnoesia: Thesis Faculty of Dentistry, Universitas Indnoesia; 2012.

8. Lenni. The dynamics of MMP-8 and TIMP-1 mRNA after the Application of Rosella Extract Gel (Hibiscus sabdariffa) on the Denture Crown of Patients with Gingivitis Dissertation. Indonesia: University of Gadjah Mada; 2016

9. Kusumastuti E, Handajani J, Susilowati H. Cox-2 Expression and Neutrophil Amount of Inflammatory Phase in the Wound Healing Process after Systemic Giving Ethanolic Rosella Extract (Hibiscus sabdariffa) Study in vivo on Wistar Rats. Indonesia: University of Gadjah Mada; 2014.

10. Komang D.The Effect of Giving Rosella Petal Extract (Hibiscus sabdariffa L.) on Osteoclast and Osteoblast Cells in Experimental Periodontitis (Ligation Technique) Male Wistar Rat Thesis. Indonesia: Universitas Jember; 2013.

11. Florencio-silvia R, Sasso GR, Sasso-Cerri E, Simoes MJ, Cerri PS, Biology of bone tissue: Structure, function, and factors that influence bone cells. Bio Med Res Int 2015;2015:1-17. 